\title{
RB1 Gene Mutation Negative
}

National Cancer Institute

\section{Source}

National Cancer Institute. RB1 Gene Mutation Negative. NCI Thesaurus. Code C153496.

A genetic finding indicating that RB1 gene mutations have not been detected in a sample. 